\title{
Ecology Service Tumbuhan Herba untuk Lebah Trigona sp.
}

\section{Ecology Service of Herbacious Plants for Trigona's Bee}

\author{
RISMAYANTI*, TRIADIATI, RIKA RAFFIUDIN \\ Departemen Biologi, Fakultas Matematika dan Ilmu Pengetahuan Alam, \\ Institut Pertanian Bogor, Kampus Dramaga, Bogor 16680
}

Diterima 26 November 2014/Disetujui 23 Desember 2014

\begin{abstract}
Herbaceous plants are able to flower any time, give them opportunity to interact with insects. This study aimed to analyze the diversity of pollen collected by Trigona sp. in herbaceous ecosystem and counted the percentage of pollen viability from the pollen basket. Trigona's nest was adapted at plot and the herbaceous plants with their pollen were identified. Pollen were took from hind legs at $07.00,08.00$ and $09.00 \mathrm{am}$. Pollen slide were make by acetolysis and SEM methods. Pollen were identified and examined of viability. Identification herbaceous plants and their pollen on plot showed that there were 7 herbaceous plants: Kyllinga monocephala, Cleome rutidosperma, Pennisetum polystachyon, Ageratum conyzoides, Brachiaria mutica, Cyperus orodatus, and Eleutheranthera ruderalis. Otherwise pollen which were collected by Trigona sp. consist of 11 kinds of pollen from 6 families, that were Sapindaceae, Leguminoceae, Loranthaceae, Malvaceae, Symplocaceae, and unidentified family.Viability of pollen ranged from $88.8 \%$ to $99.8 \%$. The result of identification herbacious plants and pollen that were taken by Trigona sp. indicated that there was not similarity therefore, it was no interaction between herbaceous plants in the plot with Trigona sp.
\end{abstract}

Key words: herbaceous plants, interaction, pollen, Trigona sp., viability

\section{PENDAHULUAN}

Hubungan antara individu satu dengan individu lain yang dapat menghasilkan suatu keuntungan, kerugian, atau tidak terdapat pengaruh atau netral disebut dengan interaksi. Macam-macam interaksi yaitu netralisme, competition (amensalisme), mutualisme, parasitisme, dan komensalisme. Salah satu jenis interaksi yaitu mutualisme merupakan interaksi yang saling menguntungkan bagi kedua belah pihak (Booth et al. 2003). Contoh dari interaksi mutualisme yaitu proses penyerbukan dimulai dari transfer polen atau serbuk sari ke kepala putik (stigma) selanjutnya diikuti pertumbuhan tabung polen melalui putik dan pembuahan bakal biji (Harrera et al. 2002).

Penyerbukan dapat dibantu dengan cara biotik (manusia, kelelawar, burung, dan serangga) dan abiotik (angin dan air) (Barth 1991). Salah satu serangga yang berperan pada penyerbukan adalah Trigona sp.

Ecology merupakan ilmu yang mempelajari interaksi antara organisme dengan lingkungannya sedangkan ecosystem adalah rangkaian atau sistem dari interaksi organisme dengan lingkungan.

*Penulis korespondensi. Phone: +62-81218850773, E-mail: rismayanti25@gmail.com
Contoh dari ecosystem yaitu ketersediaan nutrisi di alam yang dapat melayani kebutuhan untuk memenuhi kehidupan serangga polinator seperti Trigona sp. dipengaruhi oleh faktor lingkungan (suhu, kelembapan, dan curah hujan) (Rodriguez dan Frank 1987). Faktor lingkungan tersebut dapat mempengaruhi aktivitas serangga dalam mencari ketersediaan nutrisi. Tumbuhan merupakan salah satu pendukung ecosystem service sebagai sumber nutrisi bagi serangga, salah satunya adalah tumbuhan herba yang merupakan tumbuhan yang mudah ditemukan dan pertumbuhannya cepat. Selain itu, herba berbunga setiap saat dan tidak dipengaruhi oleh musim atau iklim. Oleh karena itu, perlu dianalisis interaksi tumbuhan herba dengan Trigona sp. jika serangga tersebut dipelihara dengan keadaan ekosistem tumbuhan herba yang tidak terdapat pohon.

\section{BAHAN DAN METODE}

Identifikasi Polen dan Tumbuhan Herba. Dua koloni Trigona sp. yang dipelihara di dalam kotak diletakkan di plot berukuran $20 \times 20 \mathrm{~m}$. Tumbuhan herba dalam plot dikoleksi dan dibuat spesimen herbarium dilakukan dengan cara tumbuhan herba dicuci dengan air bersih, dikeringanginkan, 
disemprot dengan alkohol $70 \%$, kemudian posisi bagian-bagian tumbuhan dirapikan dengan alas berupa kertas koran, ditekan dengan sasak, dan dimasukkan ke dalam oven selama tiga hari pada suhu $45^{\circ} \mathrm{C}$. Spesimen tumbuhan herba diidentifikasi menggunakan buku Flora untuk Sekolah Indonesia (Steenis 1988) dan Weeds of Rice in Indonesia (Soerjani et al. 1987).

Sampel polen tumbuhan herba dalam plot dikoleksi dengan cara pengambilan bunga segar. Pengamatan sampel polen dilakukan dengan cara polen langsung diletakkan di kaca preparat, kemudian diamati menggunakan mikroskop cahaya. Ciri morfologi polen dideskripsi menggunakan istilah-istilah mengikuti Pollen Flora of Taiwan (Huang 1972), Australasia Pollen and Spore Atlas (http://apsa.anu.edu.au/) (APSA 2007), University of Arizona Catalog of Internet Pollen and Spore Images (http://www.geo.arizona.edu) (The University of Arizona 2014), Structure of pollen apertures in the detarieae sensu stricto (Leguminosae: Caesalpinioideae) with particular reference to underlying structures (Zwischenkorper) (Banks 2003).

Proses Adaptasi dan Pengambilan Polen pada Lebah Trigona sp. Sarang Trigona sp. yang telah dipindahkan ke dalam kotak dari sumber sarang diadaptasi selama tiga minggu di Arboretum Lanskap. Polen diambil dari tungkai belakang Trigona sp. yang akan memasuki sarang dengan cara lebah ditangkap menggunakan jaring serangga. Setelah mendapatkan polen kemudian polen dimasukkan ke amplop kecil berukuran 5 x $8 \mathrm{~cm}$. Pengambilan polen pada tungkai Trigona sp. dilakukan pada pukul 07.00, 08.00, dan 09.00 selama tiga hari.

Polen yang diambil dari tungkai Trigona sp. pada pukul 07.00, 08.00, dan 09.00 hari ke-1, 2, dan 3 dengan lingkungan pendukung tumbuhan herba. Akan tetapi, pengambilan polen pada hari ke-4 dilakukan tanpa adanya tumbuhan herba karena adanya masalah teknis, tumbuhan herba tersebut telah dipangkas. Masalah teknis lainnya adalah polen yang diambil pada hari ke-1 dan 2 berasal dari koloni 1 dan 2 sedangkan pada hari ke-3 dan 4 polen diambil hanya dari koloni 1 karena koloni 2 Trigona sp. mati akibat faktor lingkungan seperti air hujan yang masuk kedalam sarang dan cendawan yang dapat merusak sarang Trigona sp.

Uji Viabilitas dan Identifikasi Polen. Uji viabilitas polen dilakukan setiap hari yaitu dari hari ke-1 sampai hari ke-3 yang telah dikumpulkan pada pukul 07.00, 08.00, 09.00. Polen yang telah dikumpulkan tersebut langsung diuji viabilitas.
Polen diuji dengan metode pewarnaan menggunakan pewarna $\mathrm{I}_{2} \mathrm{KI} 1 \%$. Polen atau sel akan berwarna biru karena terpengaruh larutan $\mathrm{I}_{2} \mathrm{KI}$ maka polen tersebut viabel atau mengandung karbohidrat (Sutrian 1992).

$$
\% \text { Viabilitas polen }=\frac{T}{T+M} \times 100 \%
$$

Keterangan: T: polen viabel

M: polen non viabel

Preparasi polen dilakukan menggunakan dua metode: (1) metode acetolysis $\left(\mathrm{H}_{2} \mathrm{SO}_{4} 95 \%\right.$ dan acetic anhydrid $98.5 \%$ dengan perbandingan 1:9), dan (2) metode Scanning Electron Microscope (SEM). Untuk mengetahui jenis polen yang didapatkan dari tungkai Trigona sp., polen tersebut dicocokkan dengan polen tumbuhan herba dari lokasi penelitian yang telah diidentifikasi.

Preparasi polen dengan metode acetolysis yaitu polen dimasukkan ke tabung cupsidal,diberi $1 \mathrm{~mL}$ $\mathrm{KOH} 10 \%$, didiamkan selama 5 menit, kemudian disentrifugasi dengan kecepatan $3500 \mathrm{rpm}$ selama 10 menit. Supernatan dibuang dan ditambahkan $1 \mathrm{~mL}$ akuades, kemudian disentrifugasi dengan kecepatan $3500 \mathrm{rpm}$ selama 10 menit. Polen dicuci dengan akuades sebanyak dua kali. Setelah pencucian supernatan dibuang, kemudian pada polen ditambahkan $0.5 \mathrm{~mL}$ asam asetat glasial (100\%), dan disentrifugasi pada kecepatan 3500 rpm selama 10 menit. Supernatan dibuang dan polen diberi $1 \mathrm{~mL}$ larutan acetolysis $\left(\mathrm{H}_{2} \mathrm{SO}_{4} 95 \%\right.$ dan acetic anhydrid $98.5 \%$ dengan perbandingan 1:9). Selanjutnya polen dipanaskan dalam penangas air pada suhu 90 sampai $95^{\circ} \mathrm{C}$ selama \pm 5 menit. Polen didinginkan dan disentrifugasi pada $3500 \mathrm{rpm}$ selama 10 menit, kemudian supernatan dibuang. Pada polen ditambah $0.5 \mathrm{~mL}$ asam asetat glasial $100 \%$ dan disentrifugasi pada kecepatan 3500 rpm selama 10 menit. Polen dicuci dengan akuades sebanyak tiga kali dan disentrifugasi $3500 \mathrm{rpm}$ selama 10 menit. Setelah pencucian, polen disimpan dalam gliserin $30 \%$, dan siap untuk dibuat preparat (Huang 1972).

Tahapan preparasi polen menggunakan SEM adalah: sampel direndam dalam caccodylate buffer selama tiga hari pada suhu $4{ }^{\circ} \mathrm{C}$. Kemudian sampel direndam dalam glutaraldehide $2.5 \%$ selama 24 jam dan difiksasi dalam tannic acid 3\% selama 24 jam pada suhu $4{ }^{\circ} \mathrm{C}$. Sampel didehidrasi menggunakan alkohol bertingkat $(30,50,75,95$, dan $99.9 \%$ ), selanjutnya dikeringkan dalam tertbutanol sebanyak dua kali masing-masing selama 10 menit. Proses freeze-drying sampel dilakukan selama 45 menit pada suhu $-20^{\circ} \mathrm{C}$. Proses mounting (penataan) spesimen dilakukan di atas permukaan stub dan dilapisi dengan emas murni. Sampel 
diamati dan difoto menggunakan SEM (JSM5000). Selanjutnya polen dicocokkan dengan polen yang ditemukan dengan referensi. Keanekaragaman polen yang dibawa oleh tungkai Trigona sp. diamati dengan pengukuran polen menggunakan aplikasi image $\mathrm{J}$ untuk mengukur ukuran masing-masing polen (http://www.rsbweb.nih.gov).

\section{HASIL}

Hasil identifikasi tumbuhan herba yang diamati pada bulan Februari sampai April 2014 menunjukkan bahwa terdapat tujuh spesies tumbuhan herba berbunga di dalam plot pemeliharaan Trigona sp. yaitu Kyllinga monocephala (Cyperaceae), Cyperus orodatus (Cyperaceae), Cleome rutidosperma (Cleomaceae/Capparidaceae),Pennisetumpolystachyon (Poaceae), Brachiaria mutica (Poaceae), Ageratum conyzoides (Asteraceae), Eleutheranthera ruderalis (Asteraceae/Compositae) (Tabel 1). Sedangkan hasil analisis dan identifikasi polen dari tungkai Trigona sp. dengan metode acetolysis dan SEM yaitu pertama metode acetolysis diperoleh polen dari famili tumbuhan Loranthaceae tipe A, Leguminosae tipe B, Sapindaceae tipe D, Myrtaceae tipe E dan satu jenis polen belum dapat diidentifikasi pada tingkat famili yaitu tipe $\mathrm{C}$ (Tabel 3). Kedua metode SEM (Tabel 4) memiliki 7 tipe polen dari 3 famili yang termasuk ke dalam Malvaceae (tipe F dan G), Symplocaceae (tipe H dan J), Leguminosae (tipe I, $\mathrm{K}, \mathrm{B})$. Perbedaan famili tersebut dapat dilihat dari perbedaan bentuk morfologi polen (bentuk, ukuran, tipe aperture) (Tabel 4).

Tabel 1. Bunga dan polen tumbuhan herba dalam plot pemeliharaan Trigona sp.

\begin{tabular}{|c|c|}
\hline Morfologi bunga & Morfologi polen \\
\hline \multicolumn{2}{|c|}{ Kyllinga monocephala (Cyperaceae) } \\
\hline & $50 \mu \mathrm{m}$ \\
\hline $\begin{array}{l}\text { Letak terminal, tersusun } \\
\text { atas spikelet-spikelet } \\
\text { dalam kapitulum (bonggol) } \\
\text { yang padat, setiap spikelet } \\
\text { terdiri atas braktea (glume } \\
\text { kosong), dan beberapa floret, } \\
\text { floret biseksual, tersusun } \\
\text { atas glume, benang sari 3, } \\
\text { kepala sari berbentuk linier, } \\
\text { putik dengan kepala putik } \\
\text { bercabang dua (bifid). }\end{array}$ & $\begin{array}{l}\text { Deskripsi polen spesies } \\
\text { Kyllinga monocephala: } \\
\text { bentuk polen dari bidang } \\
\text { polar subspheroidal, ukuran } \\
27-29 \times 26-35 \text { x } 27-33 \\
\mu \mathrm{m}, \text { memiliki 4-aperturate } \\
\text { (Huang 1972). }\end{array}$ \\
\hline
\end{tabular}

Tabel 1. Lanjutan

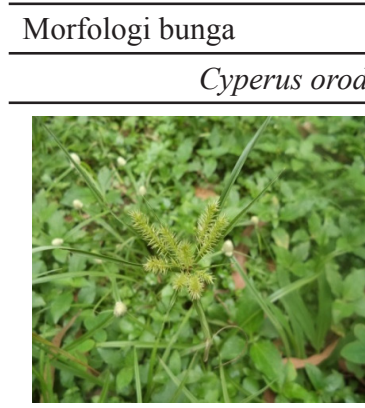

Letak bunga terminal, tersusun atas spikeletspikelet bulir yang tersusun menjari, setiap spikelet terdiri atas dua braktea (glume kosong), dan beberapa floret, floret biseksual, tersusun atas glume benang sari 3, kepala sari berbentuk linier, putik dengan kepala putik bercabang dua (bifid).

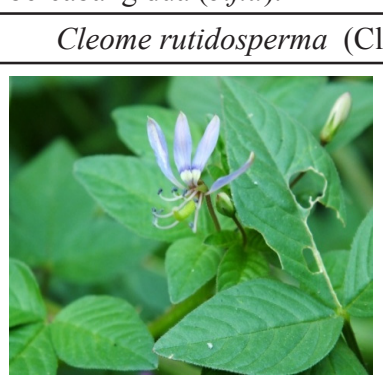

Bunga tunggal, letak bunga aksilar, simetri bunga zygomorf, biseksual, sepal 4, hijau; petal 4 berwarna merah muda sampai ungu; benang sari 6-7 bebas; kepala sari linier longitudinal; putik 1.
Morfologi polen

(Cyperaceae)

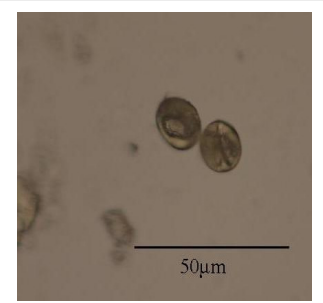

Deskripsi berdasarkan famili polen Cyperaceae yaitu: bentuk polen dari bidang pandang, subspheroidal, ukuran $21-60$ x 25-95 x 23-70 $\mu \mathrm{m}$, memiliki 1-4 aperturate (Huang 1972).

\begin{tabular}{ll} 
& $\begin{array}{l}\text { vestibulum, club, common } \\
\text { (Huang 1972). }\end{array}$ \\
\hline Pennisetum polystachyon (Poaceae)
\end{tabular}

Deskripsi berdasarkan famili polen Capparidaceae yaitu: bentuk polen dari bidang equatorial prolatespheroidal, ukuran 17-30 x 15-25 $\mu \mathrm{m}$, memiliki aperture 3-colporate, tipe aperture (polar view) vestibulum, club, common (Huang 1972).

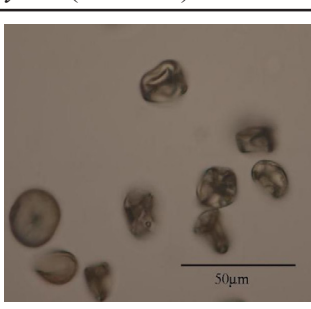

Deskripsi berdasarkan famili polen Poaceae yaitu: pandang equatorial spheroidal, memiliki aperture 1-porate (ulcerate), tipe aperture (polar view) drop (Huang 1972). 
Tabel 1. Lanjutan

\begin{tabular}{ll}
\hline Morfologi bunga & Morfologi polen \\
\hline Brachiaria mutica (Poaceae) \\
\hline
\end{tabular}

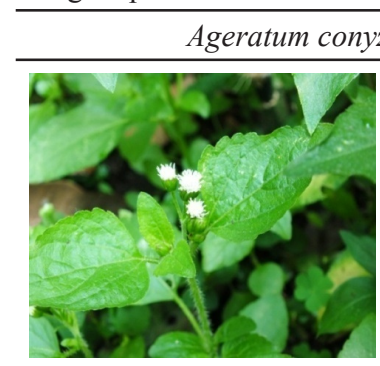

Letak bunga terminal dan aksilar; bunga majemuk bongkol, bunga bongkol tersusun dalam perbungaan payung, tersusun atas bunga tabung yang dilindungi phyllaris; biseksual; buah dilengkapi dengan pappus bersisik.

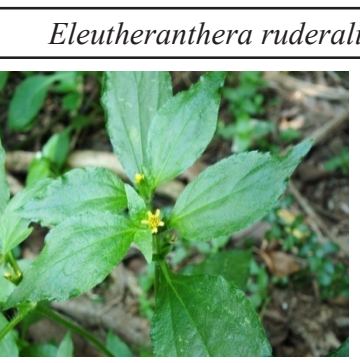

Letak bunga terminal dan aksilar; bunga bongkol terdiri atas bunga tabung dan bunga tepi; bunga tepi dengan petal berwarna kuning; benang sari dengan kepala sari berlekatan, tumpul; putik bercabang dua.

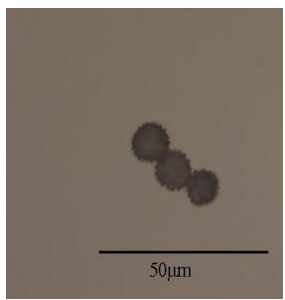

Deskripsi polen spesies Ageratum conyzoides: bentuk polen dari bidang polar sub spheroidal, ukuran 18-25 x 18-26 $\mu \mathrm{m}$, memiliki aperture 3(-4) colporate (Huang 1972).
Bentuk polen dari bidang polar lobate, memiliki aperture 3-porate, tipe aperture (polar view) common .

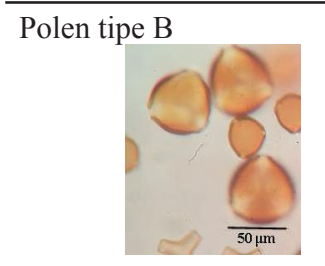

Bentuk polen dari bidang polar circular, memiliki aperture 3-colporate; tipe aperture (polar view) drop.

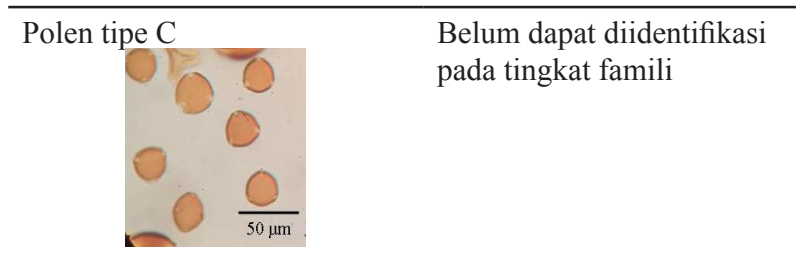

Bentuk polen dari bidang polar circular, memiliki aperture 3-porate; tipe aperture (polar view) atrium.

Polen tipe D

Bentuk polen dari bidan polar semi-angular; memiliki aperture 3(-4)-colporate; tipe aperture (polar view) common, labrum, vestibulum (Huang 1972).

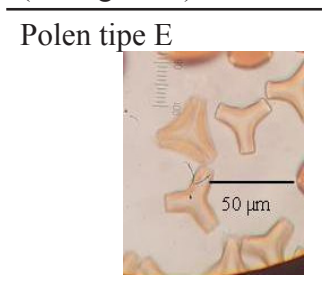

Bentuk polen dari bidang polar semi lobate, memiliki tipe aperture 3-4-colporate.

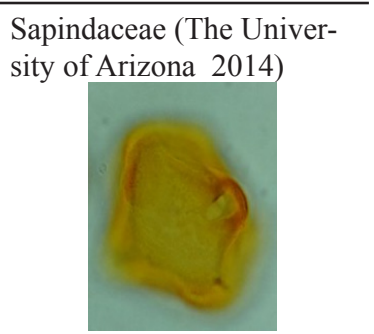

Leguminosae (Banks 2003)

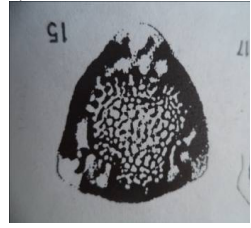

Loranthaceae (Huang 1972)

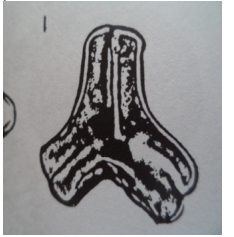

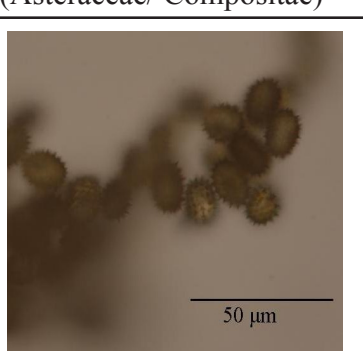

Deskripsi berdasarkan polen famili Compositae yaitu: bentuk polen dari bidang equatorial suboblate sampai prolate, ukuran $12-53$ x 12-60 $\mu \mathrm{m}$, memiliki aperture aperture 3-colpate, 2-4-colporate, atau fenestrate; tipe aperture (polar view) equatorial transversally elliptic atau circular (Huang 1972). 
Tabel 4. Identifikasi polen di tungkai Trigona sp. berdasarkan metode SEM.

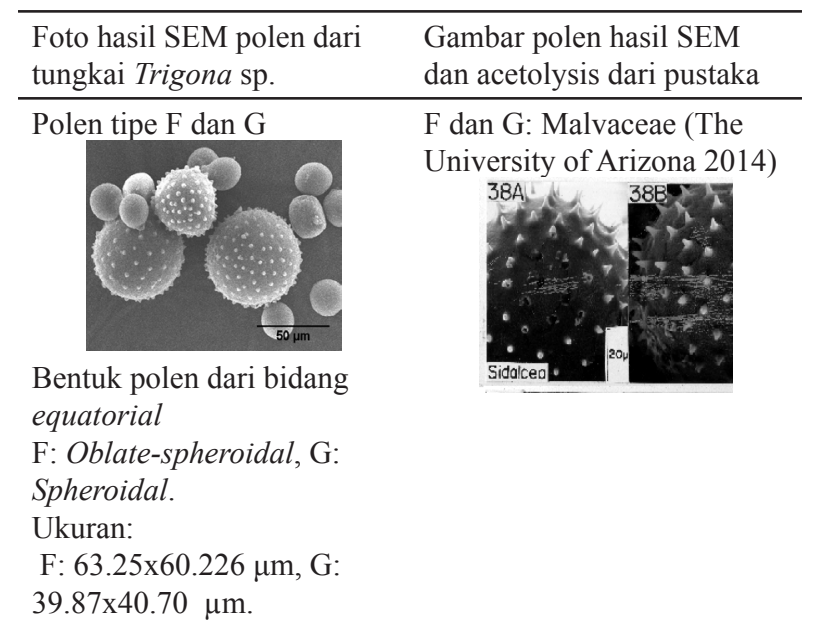

Tabel 4. Lanjutan.

\begin{tabular}{ll}
\hline $\begin{array}{l}\text { Foto hasil SEM polen dari } \\
\text { tungkai Trigona } \text { sp. }\end{array}$ & $\begin{array}{l}\text { Gambar polen hasil SEM } \\
\text { dan acetolysis dari pustaka }\end{array}$ \\
\hline Polen tipe B & Leguminosae (Huang 1972) \\
& \\
Bentuk polen dari bidang \\
polar semi-angular ukuran \\
75.08 x 73.01 $\mu$ m, memiliki \\
aperture 3-colporate.
\end{tabular}

Tabel 2. Persentase (\%) viabilitas polen pada tungkai Trigona sp.

\begin{tabular}{lccc}
\hline \multirow{2}{*}{ Pukul } & \multicolumn{3}{c}{ Hari ke- } \\
\cline { 2 - 4 } & 1 & 2 & 3 \\
\hline 07.00 & 95.0 & 99.3 & 97.9 \\
08.00 & 91.9 & 96.2 & 97.7 \\
09.00 & 98.7 & 99.8 & 88.8 \\
\hline
\end{tabular}

Polen dari tungkai Trigona sp. (Tabel 3 dan 4) tidak sesuai dengan polen dari tumbuhan yang terdapat di dalam plot berukuran $20 \times 20 \mathrm{~m}$ (Tabel 1). Jenis polen yang dibawa oleh Trigona sp. didominasi oleh famili Leguminosae, jenis tumbuhan dari famili tersebut yang diketahui tumbuh di lahan Arboretum Lanskap adalah Leucaena sp., Mimosa sp., dan Acacia sp. Terdapat pula jenis tumbuhan berbunga lain, yaitu Psidium guajava, Saraca indica, dan Spathodea sp.

Pengambilan polen dari tungkai Trigona sp. selama 4 hari memiliki keanekaragaman dan keragaman yang berbeda. Polen pada hari ke-4 memiliki keanekaragaman dan keragaman yang berbeda dibandingkan pada hari ke-1,2 dan 3 . Proses uji viabilitas polen menggunakan pewarna $\mathrm{I}_{2} \mathrm{KI}$ pada pukul $07.00,08.00$ dan 09.00 selama 3 hari berkisar antara $88.8 \%$ sampai $99.8 \%$ (Tabel 2) yang menunjukkan bahwa polen yang dibawa oleh Trigona sp. memiliki kualitas viabiltas yang tinggi untuk dibawa kesarangnya.

\section{PEMBAHASAN}

Hasil pengamatan tumbuhan herba di dalam plot berukuran $20 \times 20 \mathrm{~m}$ menunjukkan bahwa bunga tumbuhan herba di dalam plot didominasi oleh tipe bunga telanjang atau bunga tanpa perhiasan bunga (sepal atau petal) seperti $K$. monocephala, $P$. polystachyon, B. mutica, dan $C$. orodatus. Bunga lengkap dan simetri zygomorf dijumpai pada C. rutidosperma. Eleutheranthera ruderalis

Bentuk polen dari bidang equatorial prolate, ukuran 30.70x64.19 $\mu \mathrm{m}$, memiliki aperture 3 colporate.

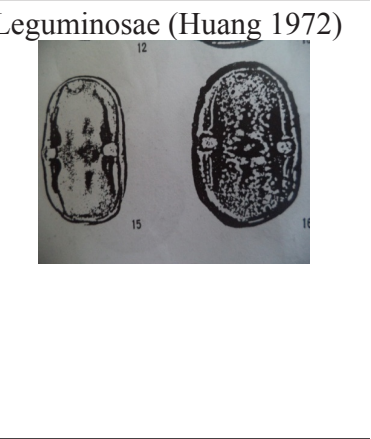


mempunyai simetri bunga zygomorf pada bunga tepi dan aktinomorf pada bunga tabung. Ageratum conyzoides mempunyai simetri bunga aktinomorf. Bentuk dan warna bunga tumbuhan herba yang terdapat di dalam plot tersebut diduga menjadi salah satu faktor penyebab tidak terjadinya interaksi dengan tumbuhan herba di dalam plot, karena menurut Dahelmi (2012) serangga ordo Lepidoptera, Hymenopera, Diptera banyak mengunjungi bunga yang berbentuk simetri bilateral (zygomorf) atau mempunyai landasan (landing pad) untuk pendaratan serangga. Selain itu daya tarik serangga terhadap bunga yaitu terdapat daya tarik primer dan sekunder. Daya tarik primer adalah polen dan nektar sedangkan daya tarik sekunder bentuk dan warna bunga (Faegri dan Pijl 1971). Tipe bunga yang tidak mempunyai perhiasan dapat dihinggapi oleh serangga jika bunga tersebut memiliki volume dan konsentrasi nektar yang sesuai dengan keinginan serangga.

Hasil identifikasi polen dari tungkai Trigona sp. berdasarkan metode acetolysis dan SEM menunjukkan bahwa tidak terdapat persamaan antara polen yang terdapat di dalam plot dengan polen yang terdapat di tungkai Trigona sp. selama 4 hari pengamatan. Hal ini menunjukkan bahwa Trigona sp. mencari polen di luar plot karena plot yang berukuran $20 \times 20 \mathrm{~m}$ tersebut tidak menyediakan kebutuhan Trigona sp., sebagai ecosystem service dan Trigona sp. dapat mendeteksi polen dengan penciuman menggunakan antena hingga $29 \mathrm{~m}$ dari sarang (Nieh et al. 2004). Selain itu, Polen yang dibawa tungkai Trigona sp. diantaranya berasal dari famili Leguminosae dan Myrtaceae. Hasil penelitian yang dilakukan oleh Danaraddi (2007) di Dharwad, India juga menunjukkan bahwa polen yang diambil oleh serangga penyerbuk Trigona iridipennis mempunyai kesamaan famili yaitu berasal dari kedua famili tumbuhan tersebut.

Uji viabilitas polen digunakan untuk mengetahui kandungan pati atau karbohidrat pada polen yang diamati. Hasil dari uji viabilitas polen yang dibawa oleh Trigona sp. menunjukkan bahwa polen yang dibawa oleh Trigona sp. merupakan polen yang mempunyai kandungan karbohidrat atau pati dengan persentase viabilitas berkisar antara $88.8 \%$ sampai 99.8\% (Tabel 2). Polen yang dibawa oleh Trigona sp. akan digunakan sebagai pakan oleh koloni. Setiap anggota koloni akan bertukar informasi untuk mendapatkan sumber pakan (Biesmeijer dan Slaa 2004).

Jenis polen yang ditemukan pada pukul 07.00 lebih beragam dibandingkan waktu penangkapan lainnya (Tabel 5). Hal ini disebabkan oleh waktu anthesis bunga sebagian besar pada pagi hari, contohnya famili Leguminosae dari jenis Acacia hybrid (Acacia mangium X Acacia auriculiformis) asal daerah tropis Thailand mulai mengalami

Tabel 5. Pengambilan polen dari tungkai Trigona sp. setiap jam berdasarkan tipe polen di Tabel 3 dan 4

\begin{tabular}{|c|c|c|c|c|c|c|}
\hline \multirow{2}{*}{ Metode } & \multirow{2}{*}{ Hari ke- } & \multirow{2}{*}{ Tipe Polen } & \multirow{2}{*}{ Famili } & \multicolumn{3}{|c|}{ Pengambilan polen pada pukul } \\
\hline & & & & 07.00 & 08.00 & 09.00 \\
\hline \multirow[t]{16}{*}{ Acetolysis } & 1 & A & Loranthaceae & $\sqrt{ }$ & $\sqrt{ }$ & $\sqrt{ }$ \\
\hline & & B & Leguminosae & $\sqrt{ }$ & - & $\sqrt{ }$ \\
\hline & & $\mathrm{C}$ & Belum dapat diidentifikasi pada tingkat famili & $\sqrt{ }$ & $\sqrt{ }$ & $\sqrt{ }$ \\
\hline & & $\mathrm{D}$ & Sapindaceae & - & - & - \\
\hline & & $\mathrm{E}$ & Myrtaceae & $\sqrt{ }$ & - & - \\
\hline & 2 & A & Loranthaceae & - & - & - \\
\hline & & B & Leguminosae & $\sqrt{ }$ & $\sqrt{ }$ & $\sqrt{ }$ \\
\hline & & $\mathrm{C}$ & Belum dapat diidentifikasi pada tingkat famili & $\sqrt{ }$ & $\sqrt{ }$ & $\sqrt{ }$ \\
\hline & & $\mathrm{D}$ & Sapindaceae & - & - & - \\
\hline & & $\mathrm{E}$ & Myrtaceae & - & - & - \\
\hline & & $\mathrm{B}$ & Leguminosae & $\sqrt{ }$ & $\sqrt{ }$ & $\sqrt{ }$ \\
\hline & 3 & A & Loranthaceae & - & - & - \\
\hline & & $\mathrm{B}$ & Leguminosae & $\sqrt{ }$ & $\sqrt{ }$ & $\sqrt{ }$ \\
\hline & & $\mathrm{C}$ & Belum dapat diidentifikasi pada tingkat famili & $\sqrt{ }$ & $\sqrt{ }$ & $\sqrt{ }$ \\
\hline & & $\mathrm{D}$ & Sapindaceae & $\sqrt{ }$ & $\sqrt{ }$ & $\sqrt{ }$ \\
\hline & & $\mathrm{E}$ & Myrtaceae & - & - & - \\
\hline \multirow[t]{7}{*}{ SEM } & 4 & $\mathrm{~F}$ & Malvaceae & $\sqrt{ }$ & $\sqrt{ }$ & - \\
\hline & & $\mathrm{G}$ & Malvaceae & $\sqrt{ }$ & $\sqrt{ }$ & - \\
\hline & & $\mathrm{H}$ & Symplocaceae & $\sqrt{ }$ & $\sqrt{ }$ & - \\
\hline & & I & Leguminosae & $\sqrt{ }$ & - & - \\
\hline & & $\mathrm{J}$ & Symplocaceae & $\sqrt{ }$ & - & - \\
\hline & & B & Leguminosae & $\sqrt{ }$ & $\sqrt{ }$ & - \\
\hline & & $\mathrm{K}$ & Leguminosae & - & - & $\sqrt{ }$ \\
\hline
\end{tabular}

Keterangan: $\sqrt{ }$ terdapat polen dan - tidak terdapat polen. 
Tabel 6. Keanekaragaman polen pada tungkai Trigona sp. hasil metode acetolysis dan SEM

\begin{tabular}{cl}
\hline Tipe Polen & \multicolumn{1}{c}{ Famili } \\
\hline A & Loranthaceae \\
B & Leguminosae \\
C & Belum dapat diidentifikasi pada tingkat famili \\
D & Sapindaceae \\
E & Myrtaceae \\
F & Malvaceae \\
G & Malvaceae \\
H & Symplocaceae \\
I & Leguminosae \\
J & Symplocaceae \\
K & Leguminosae \\
\hline
\end{tabular}

anthesis sempurna pada pukul 05.00 pagi hari (Sornsathapornkul dan Owens 1998), selain itu salah satu bunga yang terdapat di Indonesia yang mengalami anthesis pada pagi hari yaitu bunga gaharu (Gyrinops versteegii pada pukul 08.00 (Khoerani 2013). Selain itu keanekaragaman dan keragaman polen pada hari ke-4 terlihat berbeda dari pada hari ke-1,2 dan 3 karena pada hari ke-4 terjadi kesalahan teknis yang diakibatkan tumbuhan herba telah dipangkas sehingga Trigona sp. harus mencari pakan tumbuhan yang lain selain hari ke$1,2,3$.

Keanekaragaman polen yang dikoleksi oleh Trigona sp. terdiri atas sebelas tipe polen dari enam famili tumbuhan, yaitu Sapindaceae, Leguminosae, Loranthaceae, Malvaceae, Symplocaceae, Myrtaceae. Viabilitas polen yang dikoleksi dari tungkai Trigona sp. berkisar antara $88.8 \%$ sampai $99.8 \%$. Hasil identifikasi polen menunjukkan bahwa tidak terdapat kesesuaian antara polen pada plot tempat Trigona sp. dipelihara dengan polen yang dibawa Trigona sp. selama 4 hari pengamatan.

\section{UCAPAN TERIMA KASIH}

Penulis mengucapkan terima kasih kepada Departemen Arsitektur Lanskap IPB yang telah menyediakan tempat penelitian, Ibu Tini yang telah membantu dalam proses penelitian serta semua pihak yang terlibat dalam penelitian ini.

\section{DAFTAR PUSTAKA}

[APSA] Australasia Pollen and Spore Atlas. 2007. Browse Families [Internet]. [diunduh 2014 Juli 7]. Tersedia http:// apsa.anu.edu.au/.

Barth FG. 1991. Insect and Flowers The Biology of Partnership. New Jersey (US): Priceton Univ.

Banks H. 2003. Structure of pollen apertures in the detarieae sensu stricto (Leguminosae: Caesalpinioideae) with particular reference to underlying structures (Zwischenkorper). Ann Bot 92: 423-435.

Biesmeijer CJ, Slaa EJ. 2004. Information flow and organization of stingless bee foraging. Apidologie 34: 143-157.

Booth BD, SD Murphy, CJ Swanton. 2003. Weed Ecology in Natural and Agriculture System. Cambridge (US): CABI Publising.

Dahelmi, Khairiah, Nadra, Syamsuardi. 2012. Jenis-jenis serangga pengunjung bunga pacar air (Impatiens balsamina Linn.: Balsaminaceae). J Biol Univ Andalas 1: 9-14.

Danaraddi SC. 2007. Studies on stingless bee Trigona iridipennis Smith with special reference to foraging behaviour and melisso palynology at Dharwad, Karnataka [disertasi]. Dharwad (IN): University of Agricultural Sciences.

Faegri K, Pijl VDL.1971. The Principle of Pollination Ecology. Toronto (US). Pergamon Press Ltd.

Harrera et al. 2002. Floral integration, phenotypic variance structure and pollinator variation in bumble bee - pollinated Helleborus foetidus. J Ecol Biol 15:108-121.

Huang TC. 1972. Pollen Flora of Taiwan. Taiwan (TW): Nasional Taiwan University.

Khoerani. 2013. Studi pembungaan dan perkembangan buah serta viabilitas polen pohon gaharu (Gyrinops versteegii) [skripsi]. Bogor (ID): Institut Pertanian Bogor.

Nieh CJ, Felipe ALC, Ryan RY, Lillian SB, Vera LIF. 2004. Polarized short odor-trail recruitment communication by a stingless bee Trigona spinipes. Behav Ecol Sociobiol 556: 435-448.

Rodriguez JG, Frank SJR. 1987. Nutritional Ecology of Insect, Mites, Spider, and Related Invertebrates. Canada (US): A Wiley Interscience Publication.

Soerjani M, Kostermans AJGH, Tjitrosoepomo G. 1987. Weed of Rice in Indonesia. Jakarta (ID): Balai Pustaka.

Sornsathapornkul P, Owens. 1998. Pollination biology in a tropical Acacia hybrid (A. mangium Willd. $\mathrm{x} A$. auriculiformis A. Cunn. ex Benth). Ann Bot. 81:631-643.

Steenis Van CGGJ. 1988. Flora untuk Sekolah di Indonesia. Moeso S, penerjemah. Jakarta (ID): PT Pradnya Paramita. Terjemahan dari: Botany.

Sutrian Y. 1992. Pengantar Anatomi Tumbuh-Tumbuhan (Tentang Sel dan Jaringan). Jakarta (ID): Rineka Cipta.

The University of Arizona. 2014. Internet Pollen and Spore Images [Internet]. [diunduh 2014 Juli 7].Tersedia pada: http://www.geo.arizona.edu. 